\title{
Study of Kosi Flood Disaster on Migrant Children of Bihar, India
}

\author{
Dr. Renu Dewan \\ Associate Professor University Department of Psychology, Ranchi University, Ranchi (Jharkhand),INDIA
}

\begin{abstract}
The study examines the effects of sociological and psychological factors on migrant and non-migrant children in Kosi basin. The data obtained by random sampling was based on two sub-groups of Religion (Hindu-Muslim), Gender (Female-Male) and Socio - Economic Status (High-Low). A $2 \times 2 \times 2 \times 2$ factorial design was used to study the effect of above mentioned factors on migration of children. General Health Questionnaire (GHQ)-12 was applied to study the mental health of migrant and non-migrant children sample. For Analysis of the obtained data, calculation of percentages was applied. The findings indicate that percentage values of mental health scores of Hindu-Muslim low socio-economic status male-female migrant children sample were much lower than their counterparts. It proves that socio-economic status factors have strong impact on mental health of migrant children.
\end{abstract}

Key words: Flood disaster, Gender, Mental health, Migration, Religion

\section{Introduction:}

Bihar is collapsing under devastative floods, with the Kosi River changing its course after 150 years. The government which is totally unprepared for such a calamity has not been able to do anything except asking the people to leave their homes, farms and other belongings.

According to some reports, more than 4,000,000 - four million - people have been affected by this forced migration out of their homes. The river has shifted over $120 \mathrm{kms}$. Eastwards, going back to the course, it had abandoned more than 200 years ago. Fields in the flood-affected districts of Bihar remain waterlogged at many places nearly five months after the deluge. Boats are still playing in the paddy fields and farmers wondered whether the water would recede for another couple of months. Kosi flood water was normally reddish, but the villagers reported that the waters have turned blackish in this flood.

A human tragedy of unparalleled dimensions unleashed itself on millions residing in the 7 North Bihar Districts of Supaul, Araria, Madhepura, Saharsa, Purnia, Khagaria and Katihar due to a breach in eastern Kosi embankment upstream of the Indian border at Kushaha in neighbouring Nepal on the 18th of August, 2008. Following the breach, river Kosi, often referred to as the "Sorrow of Bihar", picked up a channel, it had abandoned over 200 years ago, drowning towns and numerous villages coming in the way of its newly acquired course, affecting more than 3 million people.

Five months after the Kosi deluge of August 2008, fields remained waterlogged, boats were still plying in paddy fields and thousands had lost their livelihoods as their cultivable lands had been permanently ruined. people were migrated in search of livelihood. The fact is their only source of income - the paddy fields have been lost forever.

Characteristics of the Survey Districts

The five flood-affected districts are among the poorest districts in India. In 2001, the total population of the five districts was about 8.3 million. The population was overwhelmingly rural, ranging from 91.7 percent in Purnia and Saharsa to close to 95 percent in Araria, Madhepura and Supaul. A significant proportion of the population is Muslim, particularly in Araria and Purnia (41 and 37 percent respectively). The proportion of people belonging to schedule tribe (ST) was very small, but the proportion of schedule caste (SC) was high, especially in Madhepura and Saharsa.

Population Distribution and Social Composition of Survey Districts, 2001 DISTRICTS POPULATION \% RURAL SOCIAL COMPOSITION (Lakh)

Population SC \% ST \% Hindu \% Muslim \%

\begin{tabular}{lllllll} 
Araria & 21.6 & 93.9 & 13.6 & 1.4 & 58.5 & 41.1 \\
Madhepura & 15.3 & 95.5 & 17.1 & 0.6 & 88.6 & 11.4 \\
Purnia & 25.4 & 91.3 & 12.3 & 4.4 & 62.3 & 36.8 \\
Supaul & 17.3 & 94.9 & 14.8 & 0.3 & 82.3 & 17.4 \\
Saharsa & 15.1 & 91.7 & 16.1 & 0.3 & 85.5 & 14.4 \\
Bihar & 830.0 & 91.6 & 15.7 & 0.9 & 83.2 & 16.5 \\
\hline
\end{tabular}

Source: Census of India, 2001 


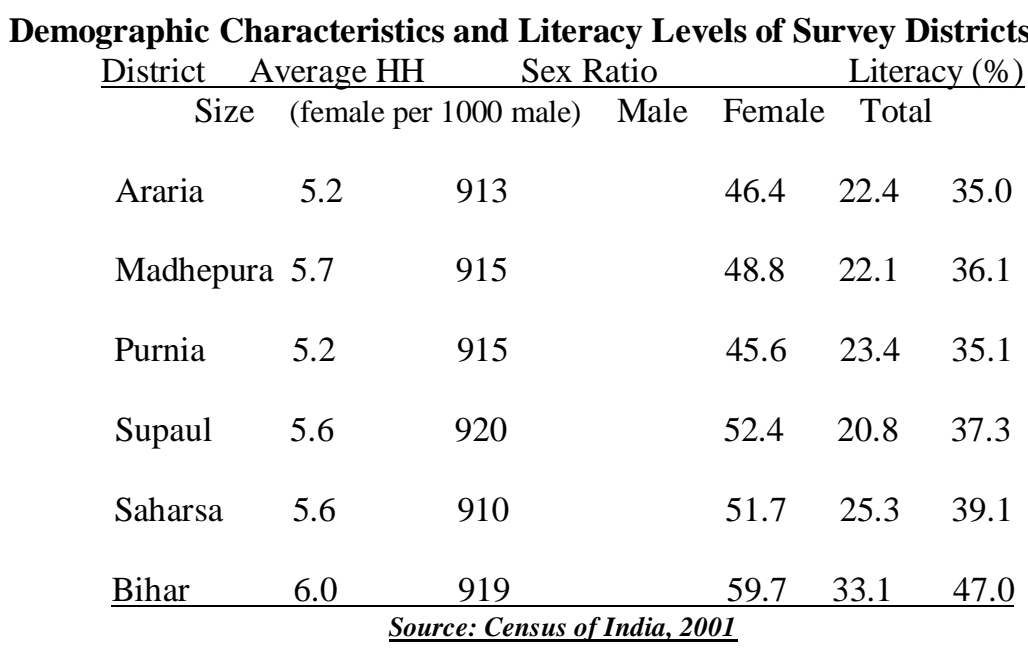

Agriculture, on which about 90 percent of the population was dependent, was largely subsistence agriculture, with very low productivity. All five districts have higher work participation rates than the average for Bihar; however, this appears to be related to widespread poverty, which pushes people to work even in activities that provide very low incomes. It is revealing that the proportion of workers engaged in nonagricultural activities ranged from as low as 7\% in Madhepura to 10\% in Saharsa, in 2001. Agricultural labourers thus constitute the majority of workers; in fact in Araria and Purnia they account for two-thirds of all workers.

\section{Occupational Profile of Workers in Survey Districts, 2001}

\begin{tabular}{|c|c|c|c|c|c|}
\hline \multicolumn{2}{|c|}{$\begin{array}{c}\text { Districts } \\
\text { of total Populations }\end{array}$} & $\begin{array}{l}6 \text { Workers } \\
\text { Agriculture }\end{array}$ & \multicolumn{3}{|c|}{$\%$ of $\mathrm{T}$} \\
\hline Iraria & 40.3 & 64.7 & 26.2 & 1.9 & 7.2 \\
\hline Iadhepura & 45.5 & 57.4 & 34.0 & 1.7 & 6.9 \\
\hline urnia & 38.9 & 66.3 & 24.0 & 1.6 & 8.1 \\
\hline upaul & 42.7 & 55.9 & 35.2 & 1.8 & 7.1 \\
\hline aharsa & 40.4 & 54.7 & 32.9 & 2.0 & 10.4 \\
\hline ihar & 34.7 & 51.0 & 31.4 & 3.7 & 13.9 \\
\hline
\end{tabular}

The report titled 'Disaster in Bihar' prepared by a four-member research team led by Dr Manish Kumar Jha after a five-day visit to the flood-affected districts of Saharsa, Supaul and Madhepura, says daily survival was likely to emerge as a major issue because Bihar is densely populated and the government does not have enough resources to create alternative livelihoods for the affected people. Large number of people, mainly labourers do not have any work to do and have to sit idle throughout the day in absence of work. When asked about work, they answered that they are willing to work and will definitely like to work and earn their livelihood if such opportunities are created, such as through the NREGA. Such people could be involved in rescue, construction of mega shelters and reconstruction work through the NREGA and paid wages for the same.

However, a large number of male and female had already started migrating from the area. While talking to victims in the relief camps and makeshift huts, one realized that thousands of people were leaving the area in search of livelihood to cities like Patna, Delhi, Ludhiana, Amritsar and several others. They were aware that their livelihoods had been gone forever and they had to begin fresh life.

Most of them were not even aware as to where they were leaving for, but it was known to them that they would had to migrate to earn a living for survival of their family. "At least 200 flood-hit families from Murliganj in Madhepura district, were rescued and brought in relief camps in Purnia, left for Punjab and Delhi in search of a livelihood" (The Hindustan Times, 4-09-08). Information about distress migration was pouring in from all across the flood affected region. 
A large number of people from the Kosi region were known to migrate annually to Delhi and Mumbai in search of menial jobs and to rural Punjab as agricultural labour. After the latest calamity, no less than 5, 00,000 people might had already left the region, (Kosi Nav Nirman Abhiyan).

There in fact, a special train was started for the migrant workers (Amrapali Express from Bihar to Punjab). The migration triggered by the Kosi floods had a devastating impact on many families, especially women and children and their overall socio-economic situation, said by Abhiyan (NGO), underlining the need for migrationreducing income-generation activities. In many families, men had migrated and women and children were living in a state of fear and anxiety. In the Kosi region, which has always been at the margins of existence and which was famous for out-migration, there people were yet to get convinced that the state would rise up to the huge task of livelihood restoration and rehabilitation.

Abhiyan (NGO) had also proposed a 'Kosi Relief Fund' and 'Reconstruction Action Plan' (20082009) to empower people to exercise their rights over their entitlements under various government schemes and to strengthen people-centric groups through sustainable livelihood focused programmes and implementation of NREGA etc. These were several other measures being planned to revive the local economy of the affected communities.

Prof. M S Swaminathan, agricultural analyst and a member of the Rajya Sabha, have underlined the need to formulate a "beyond the floods" action plan soon after the tragedy and in the case of the Bihar floods, the immediate challenge would be agricultural rehabilitation, since agriculture including crop and animal husbandry, fisheries, agro-forestry and agro-processing comprised the backbone of the livelihood security system in over $80 \%$ of the areas affected by the Kosi."

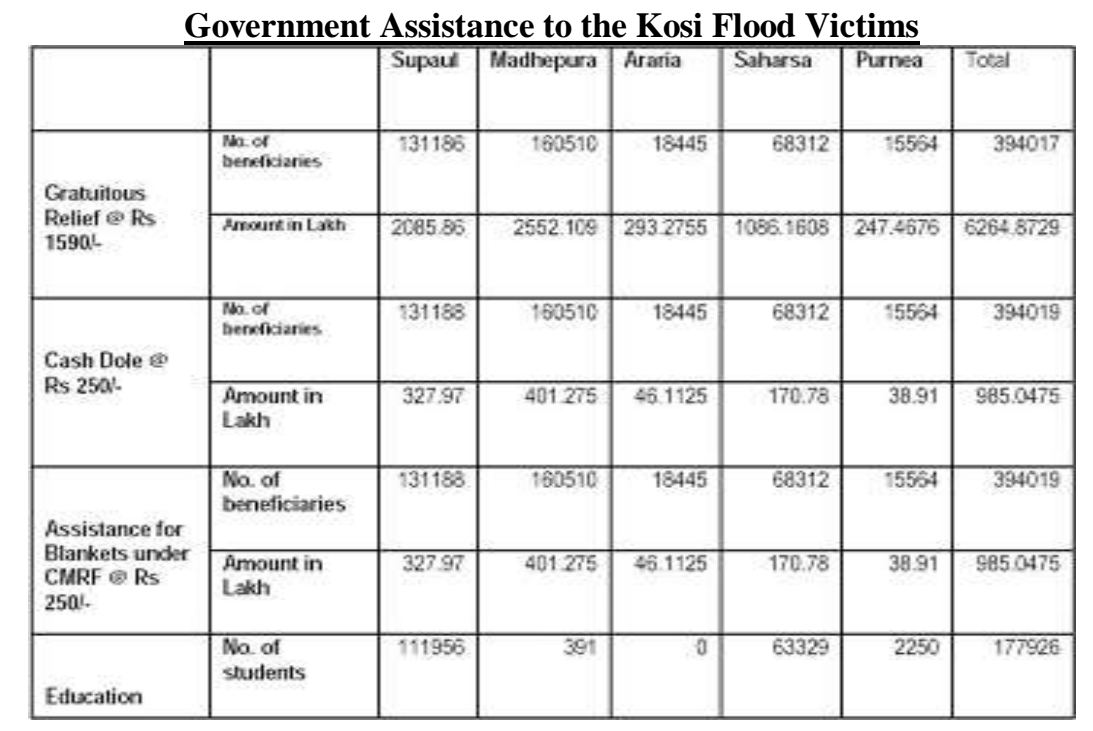

Source: Disaster Management Department, Govt. Of Bihar

'Migration has been defined broadly as a permanent or semi- permanent change in residence. No restriction is placed upon the distance of the move or upon the voluntary or involuntary nature of the act, and no distinction is made between external and internal migration' (E. S. Lee 1969,p.285).

Several studies on migration indicate that the process, volume and direction of people in their movement from one place to another are influenced by a number of such factors as geographical conditions, economic hazards, non-availability of regular and reliable occupations, educational opportunities and achievements and several other social and psychological conditions. Among which, the demographic and economic have received more attention than the others .But above all, migration is a socio-psychological phenomenon.

\section{Review of Literature}

A large number of studies on migration have been made in India and Abroad. Analysis by Banerjee (1987), Barnum (1976), Caldwell (1967), Cowling \& Metcalf (1968), Dasgupta (1984), Fawcett et. al. (1984), Mandal (1981), Nanda (1964), Rao (1982), Sengupta et.al. (1988), Srinivasan (1998), Todaro (1969), Yousef et.al.(1979) and many others are worth noting. Most of these studies have examined the rural-urban migration and given more emphasis to economic factors.

The focus of the Indian studies on migration was on the level and pattern of migration (Bardhan, 1977; Basu et.al., 1987; Bhagat, 2008; Bose, 2003; Chakarvarty, 1997; Chatterjee and Bose, 1977; Dewan, 
2006; Dyson and Pravin, 2004; Kadi and Sivamurty, 1988; Kundu, 2006; 2007; Ghosh and Sharma, 1995; Malhotra, 1974; Mitra, 1987; Narayan, 1993; Oberai and Singh, 1983; Premi, 1980; Ram, 1986; Skeldon, 1986; 2002; Srivastava, 1998; Srivastava and Kumar, 2003; Visaria, 1980; and Zachariah,et.al.2002).

The present study emphasis the impact of socio-psychological factors on migration of children of Kosi disaster in Bihar.

\section{OBJECTIVE OF THE STUDY:}

\section{Methodology}

The main objective of the study was to explore the relationship of migration with sociological factors such as religion, socio-economic status and gender as well as a psychological factor - mental health.

\section{DESIGN:}

The Design is given below:

\begin{tabular}{|l|r|r|r|r|r|r|r|r|}
\cline { 2 - 9 } \multicolumn{1}{c|}{} & \multicolumn{4}{c|}{ MIGRANT CHILDREN-160 } & \multicolumn{3}{c|}{ NON- MIGRANT CHILDREN-160 } \\
\cline { 2 - 9 } \multicolumn{1}{c|}{} & \multicolumn{2}{c|}{ HINDU-80 } & \multicolumn{2}{c|}{ MUSLIM-80 } & \multicolumn{2}{c|}{ HINDU-80 } & \multicolumn{2}{c|}{ MUSLIM-80 } \\
\cline { 2 - 9 } \multicolumn{1}{c|}{} & High SES & Low SES & High SES & Low SES & High SES & Low SES & High SES & Low SES \\
\hline MALE & 20 & 20 & 20 & 20 & 20 & 20 & 20 & 20 \\
\hline FEMALE & 20 & 20 & 20 & 20 & 20 & 20 & 20 & 20 \\
\hline
\end{tabular}

Total $=320$

\section{SELECTION OF THE SAMPLE:}

The sample for the study was 320 children (aged 10-14yrs) selected from Kosi flood area located in Bihar State of India. The sample selection was based on random technique and $2 \times 2 \times 2 \times 2$ factorial design.

In the first stage, a personal data schedule was applied on the children, aged $10-14 \mathrm{yrs}$ of the selected flood areas of Kosi basin in Bihar and from the collected information, the children sample was divided into two groups: migrants and non-migrants and each of the group was further divided into two sub-groups of Religion (Hindu - Muslim), Socio-economic Status (High-Low), and Gender (Male - Female)

In total, there were 16 sub-groups, each had 20 cases and total number of the sample was 320 .

\section{MEASURES OF THE STUDY:}

The following measures were applied for collection of data:

(i) Personal Data Schedule:

It was applied to obtain information on respondents' gender, age, village, religion, family, education level, duration of migration inside and out-side the State and socio-economic status of the parents etc.

(ii) Socio-Economic Status Scale:

It was developed by Hassan (2000) consisting 12 items based on three criteria: i. Income ii.Education iii Occupation.

Respondents having monthly income of Rs.10, 000/ (Ten Thousand) and above, educational qualification of 10+2 and above and holding class - II and class - III jobs were considered High SocioEconomic Status (HSES) group and those having monthly income of Rs.5000/ (Five Thousand) or less, educational qualification of below matriculation level and working as peon, labourer, hawker etc. were considered as Low Socio-Economic Status (LSES) group.

(iii) General Health Questionnaire (GHQ) -12

This scale was made by Shamsunder et.al.1986 and Goutam et.al. 1987. It consisted 12 questions related to health problems focused on malnutrition, weight, height, anemia/hemoglobin, blood pressure, sugar level and anxiety/stress etc. It has two response alternatives (yes/no). A score of 1 was given for 'Yes' responses to positive items and 0 for 'No' responses to negative items. High scores indicate good mental health.

(iv) Interview Schedule of Motives

An Interview Schedule constructed by the researcher (Dewan, 2001) was applied on the sample to obtain information regarding the actual motivational / psychological factors such as: attraction of city life, higher wages, imitation of friends/relatives, insecurity, attraction of job, mal-adjustment, mediator as push motive, financial liabilities, frustrations of life and attraction of opposite sex/marriage to investigate the actual reasons of migration. 


\section{Results}

For analysis, percentage values of data obtained on Mental Health Questionnaire (GHQ) -12 and Interview Schedule of Motives of migrants and non-migrants in relation to two sub-groups of religion (HinduMuslim), socio-economic status (High-Low) \& gender (Male-Female) are present in following table $1 \& 2$ :

Table 1:

Percentage values (\%) of Migrant and Non-migrant sample obtained on Mental Health Questionnaire (GHQ-12)

MIGRANTS -160

$\begin{array}{lcccccc}\text { FACTORS } & \text { No } & \text { HINDU (\%) } & \text { MUSLIM (\%) } & \text { No } & \text { HINDU (\%) } & \text { MUSLIM (\%) } \\ \text { HSES } & 40 & 46.00 \% & 26.50 \% & 40 & 63.00 \% & 46.50 \% \\ \text { LSES } & 40 & 35.75 \% & 32.50 \% & 40 & 42.25 \% & 42.50 \% \\ \text { MALE } & 40 & 41.25 \% & 30.27 \% & 40 & 53.50 \% & 50.27 \% \\ \text { FEMALE } & 40 & 45.50 \% & 39.15 \% & 40 & 55.50 \% & 49.15 \%\end{array}$

A look at figures shown in above table 1, the following points are important to explain :

$>$ Migrant children compared to non-migrant children were found lower percentage of mental health scores in respect to religion, gender and socio-economic status (SES) groups.

$>$ Percentage values of mental health scores of migrant Hindu children group has found lower than nonmigrant Hindu sample of children.

$>$ Low and high socio-economic status non-migrant sample of children were found higher percentage values of mental health scores than that of migrant high and low socio-economic status group.

$>$ Percentage values of mental health of migrant male-female children group was found lower than that of non-migrant male-female sample of children.

Table 2:

Percentage values of Migrants and Non-migrant Children Sample obtained on Interview Schedule of Motives :

\begin{tabular}{|l|l|l|l|}
\hline Motives & Migrant & Non-Migrant & Total (\%) \\
\hline & 160 & 160 & 320 \\
\hline Attraction of City Life & $86.25 \%$ & $33.13 \%$ & $63.13 \%$ \\
\hline Higher Wages & $88.75 \%$ & $30.00 \%$ & $59.38 \%$ \\
\hline Imitation of Friends & $60.63 \%$ & $21.88 \%$ & $41.25 \%$ \\
\hline Insecurity & $67.50 \%$ & $17.50 \%$ & $42.50 \%$ \\
\hline Attraction of Job & $90.63 \%$ & $18.75 \%$ & $54.69 \%$ \\
\hline Mal-Adjustment & $65.63 \%$ & $15.62 \%$ & $40.63 \%$ \\
\hline $\begin{array}{l}\text { Mediator as a Push } \\
\text { motive }\end{array}$ & $82.50 \%$ & $13.75 \%$ & $48.13 \%$ \\
\hline Financial Liabilities & $76.25 \%$ & $11.25 \%$ & $43.75 \%$ \\
\hline Frustration of Life & $81.25 \%$ & $18.12 \%$ & $49.65 \%$ \\
\hline
\end{tabular}

Motivation level of migrant children as compared to non- migrant was found more higher to run for jobs towards big cities \& metros in respect of religion, socio-economic status and gender.

- $86.25 \%$ children had migrated due to attraction of big cities.

- Among them $88.75 \%$ migrant children had attraction of better wages in metros.

- $60.63 \%$ children migrated due to imitation of their friends and relatives. 
- $90.63 \%$ of the sample was migrated to big cities for attraction of better jobs.

- $82.50 \%$ of children were motivated to migrate by the mediators

- $76.25 \%$ of children sample was migrated due to financial liabilities.

- $81.25 \%$ of children have migrated to metros due to frustration of life.

\section{Conclusion}

- Mental health level of non-migrant sample was found higher than that of migrant sample of children in respect of religion, socio-economic status and gender.

- Motivation level of migrant children sample as compared to non- migrants was found higher in respect of religion, socio-economic status and gender.

\section{Recommendations:}

The study emphasizes the need to empower the deprived migrant children socially, economically and politically. The joint venture of Government, NGOs and common Citizens of the society in this endeavor is the need of the hour. researches.

The Above conclusions are not very surprising but purely tentative which need to be verified by the further

\section{References:}

[1] Banerjee. B. (1981). "Rural-Urban Migabon and Family Ties: An Analysis of Family Consideration in Migration Behaviour in India". Oxford Bulletin of Economics and Statistics, Vol., 43.No.-4,321-

[2] Bardhan, K.(1977).” Rural Employment, Wages and Markets in India: A Survey of Research”. Economic and Political Weekly, Review of Agriculture, Vol.15, June 25.

[3] Barnum, H.N (1976). "The interrelationship among social and Political variables, Economic structure and Rural Urban Migration".Economic Development and Social Change, Vol. 24 No. 4.

[4] Basu, A.M., Basu, K. and Ray, R.(1987) . "Migrants and the Native Bond: An Analysis of Micro-level Data for Delhi". Economic and Political Weekly 22 (19, 20 and 21) a 145- A 153, 1987.

[5] Bhagat, R. B.,(2008). “ Assessing the Measurement of Internal Migration in India “, Asian and Pacific Migration Research, Vol.17, No. 1. pp. 91-102.

[6] Bose, A. (2003).'”Population research : Deteriorating Scholarship, Economic and Political weekly". Vol 38. No. 44, November 1, Pp. 4637-4639.

[7] Caldwell, J.C. (1967). “African Rural Urban Migration”. New York.: Columbia University press,

[8] Chakarvarty, B.(1997). "The Census and the NSS Data on Internal Migration”. in Ashish Bose, Davendra B, Gupta, and Gaurisankar Raychaudhuri (eds.), Population Statistics in India, New Delhi: Vikas Publishing House Pvt. Ltd.

[9] Chatterjee, Atreyi and Bose, A. (1977). “ Demographic Data on Internal Migration and Urbanization from Census and NSS- An Appraisal, in Ashish Bose, Davendra B. Gupta and Gaurisankar Raychaudhuri” (eds.). Population Statistics in India, New Delhi: Vikas Publishing House Pvt. Ltd.

[10] Cowling, K. and Metcalf D (1968). “Labour Transfer from Agriculture: A Regional Analysis”. Manchester School of Economic \& Social Studies Vol. 36, No. 1.

[11] Dewan R.(2006). "Migration of Tribal and Non-Tribal Women : A Socio-Psychological Study in Jharkhand". Journal of Economic and Social Development, V.B. University, Hazaribagh, Jharkhand, Vol.1(2),62-78.

[12] Dyson, T. and Visaria, Pravin (2004). "Migration and Urbanization: Retrospective and Prospects". in Tim Dyson, Robert Cassen and Leela Visaria (eds.) Twenty- first Century.

[13] Goutam, S., Nijhawan, M., Kamal, P. (1987). Standardization of Hindi Version of Goldberg's General Health Questionnaire. Indian Journal of Pchiatry,29 (1), 63-66.

[14] Ghosh,P.P., and Sharma, A.M. (1995). "Seasonal Migration of rural Labour in Bihar". Labour \& Development, Vol.1 Kadi, A.S. and Sivamurty, M. (1988).” Interstate Migration in India: 1971-81”. Canadian studies in population, 15(1), 37-50.

[15] Kundu, Amitabh (2006). "Urbanization and Urban Governance : Search for a Perspective Beyond Neo-Liberalism". In A. Shaw ed. Indian Cities in Transition. Hyderabad: Orient Longman.

[16] Kundu, Amitabh (2007). "Proceedings of Dr. C. Chandrasekaran Memorial Lecture on Migration and Exclusionary Urban Growth in India”. IIPS Newsletter,vol. 48. Number $3 \& 4$, pp. 5-23.

[17] Mandal, R.B. (1981). "Frontiers in Migration analysis" (ed.). New Delhi:Yatan Publication

[18] Mitra, M. (1987). "Women's WORK and Household Survival Strategies: A Case study of Santhal Women's lives and Work". EWDS, New Delhi.

[19] Nanda, A.K (1964). "Pull from Cities or Push from Village”. Yojna 11th October.

[20] Oberai,A.S. and Singh,H.M.K. (1983). "Causes and Consequences of Internal Migration: A Study in Indian Punjab, Oxford University Press, Delhi.

[21] Premi. M.K (1980).” Aspect of Female Migration in India”. Economic and Political weekly. 15 (15). 714-720.

[22] Ram, Nandu (1986). "Migration and Social Mobility in India: Some Theoretical-Methodological Issues". Paper presented in 11th World Congress of Sociology, August 18-22, 2003, New Delhi.

[23] Rao, M.S.A.(1978)." Tobacco Development and labour Migrants on Planning for Labour Welfare and Development”. Economic and Political Weekly, 13 (29).

[24] Rao, M.S.A. (1982). "Migrant Female Graders of Tobacco in Andhra Pradesh". Paper presented at the Workshop on Social Economic and Demographic aspects of Migration, Feb-23-24, University of Delhi, New Delhi.

[25] Sengupta, A. and Desai, R. (1988). "Urban Rural Differentials: Effects on the family and women on Social Impact of Urbanization". Report prepared for the National Conference on Urbanisation, Ministry of Urban Development, TISS, Bombay.

[26] Shamsunder, C., Murthy, S.K., Prakash, N., Subhakrishna, D.K.1986.Psychiatric Morbidity in a general practice in an Indian city. British Medical Journal, 292: 1713-1715. 
[27] Srinivasan, S. (1998). "Breaking Rural Bonds through migration: The failure of Development for women in India". Journal of Comparative Family Studies, 28 (1), 90-92.

[28] Srivastava, Ravi and Kumar, S.K. (2003). "An Overview of Migration in India, Its Impacts and Key Issues" Paper presented in Regional Conference on Migration. Development and Pro-Poor Policy Choices in Asia, June 22-24, at Dhaka.

[29] Todaro. M.P.(1969). "A Model of Labour Migration and Urban Unemployment in Low Developed Countries". American Economic Review. 59 (1)

[30] Visaria, Pravin (1980). "The Level of Pattern of Economic Activity by Migration Status in India". Demography India. 1 (1\& 2 , Yousef, N. (1979). "Women in Migration: A Third World Focus. Washington: Monograph

[31] Zachairiah, K.C., Kanna, K.P. and Rajan, S. Irdua (2002). Thiruvanathapuram: Kerela's Gulf Connection, Centre for development studies. 